\title{
Effects of Outdoor School Ground Lessons on Students' Science Process Skills and Scientific Curiosity
}

\author{
Kan Lin $\operatorname{Ting}^{1} \&$ Nyet Moi Siew ${ }^{1}$ \\ ${ }^{1}$ Faculty of Psychology and Education, Universiti Malaysia Sabah, Malaysia \\ Correspondence: Nyet Moi Siew, Faculty of Psychology and Education, Education Block, Jln UMS, 88400, \\ Universiti Malaysia Sabah, Malaysia. Tel: 60-88-320-000 ext 2532. E-mail: snyetmoi@yahoo.com
}

Received: August 1, 2014

Accepted: September 15, $2014 \quad$ Online Published: November 19, 2014

doi:10.5539/jel.v3n4p96

URL: http://dx.doi.org/10.5539/jel.v3n4p96

\begin{abstract}
The purpose of this study was to investigate the effects of outdoor school ground lessons on Year Five students' science process skills and scientific curiosity. A quasi-experimental design was employed in this study. The participants in the study were divided into two groups, one subjected to the experimental treatment, defined as "eco-hunt" group and the other had no experimental treatment, defined as control group. This study used intact four classes which consisted of 119 students and randomly assigned to the treatment $(\mathrm{n}=63)$ and control groups $(\mathrm{n}=56)$. Students' science process skill was measured by a self-developed Science Process Skills Test and students' scientific curiosity was measured using Children Scientific Curiosity Scale adapted from Harty and Beall (1984). The results showed a significant difference in post-test mean scores between students in "eco-hunt" group and control group in both students' science process skills and scientific curiosity. Follow-up comparisons on the dimensions of science process skills and scientific curiosity were analyzed and discussed. The findings of this study will provide a framework for science teachers to teach students through interesting and meaningful outdoor activities.
\end{abstract}

Keywords: outdoor school ground lessons, science process skills, scientific curiosity

\section{Introduction}

Children spend most of their waking hours in schools. It is therefore no surprise that school environment affects the mental well-being of children (Gustafsson, Szczepabski, Nelson, \& Gustafsson, 2011). Science education in elementary schools should expand beyond the four walls of the classroom as many opportunities abound in the outdoor setting for learning about science. As Charlesworth and Lind (1999) implied that children apply science concepts when they explore the outdoors, Dietz (1999) supported this by stating that children construct knowledge through meaningful experiences from outdoor. According to National Wildlife Federation (2013), abstract concepts and connections between various subject areas come to life in a schoolyard habitats sites, enhancing student comprehension and performance. The school grounds become places where students not only learn about wildlife species and ecosystems but would also sharpen up their science process skills and raise their natural curiosity (National Wildlife Federation, 2013). This inspired the present study to investigate if outdoor school ground lessons would give an effect on students' science process skills and curiosity.

The Level Two Primary School Science Curriculum in Malaysia is designed to stimulate pupils' curiosity and develop their interest as well to enable pupils to learn about themselves and the world around them through pupil-centered activities (Curriculum Development Centre, 2006). It is also designed to provide pupils with opportunities to develop science process skills and thinking skills. According to the Malaysian Standard Curriculum for Primary School (2013), science process skills are required for solving problems, seeking answers or making systematic decisions. It is a mental process that encourages critical, creative, analytic and systematic thinking. Mastering science process skills with better understanding and appropriate attitude towards science would ensure the students think effectively (Standard Curriculum for Primary School, 2013). Besides, Malaysia Standard Curriculum for Primary School (2013) is also designed to raise students' curiosity through variety of teaching and learning activities. With the use of a variety of teaching and learning methods in classroom, it is anticipated that pupils' interest in science will be enhanced. Science lessons that are not interesting will not be able to motivate pupils to learn and subsequently will affect their scientific thinking skills and curiosity. To abreast with the core objectives stated in Level Two Malaysian Standard Curriculum for Primary School, this 
study attempted to investigate if outdoor school ground lesson would affect science process skills and curiosity among Year Five students.

A number of researchers have examined the effects of outdoor lessons on students' science process skills. For example, Archie (2003), Keil et al. (2009), and Buntod, Suksringam and Singseevo (2010) claimed that students develop better in their critical thinking skills and science process skills after undergoing an environment-based education. In addition, National Foundation for Educational Research (2004) also indicated that outdoor school ground project shows positive impact on students' science process skills. Curiosity has often been highlighted as an important attribute and influencing factor with respect to students' learning (Borowske, 2005). Literature studies showed that higher curious students probably achieve better than lower curious students (Harty \& Beall, 1984) because of their exploration of events and objects for longer periods time and their use of many more senses. Curious youngsters will recall experiences longer, comprehend better and achieve a more complete learning (Harty \& Beall, 1984). In short, curiosity motivates students on their learning (Edelman, 2007). Moreover, nature is a great place to let children develop with their own curiosity, imagination, and interests (Erickson, 2008). Natural outdoor spaces foster children ability to explore and desire to know (Erickson, 2008). According to Little and Wyver (2008), learning through environment can satisfy children natural curiosity and desire for novelty.

The above-mentioned researches have provided evidence that school ground lessons can result a favor to the students' science process skills and curiosity. However, there has been little research presented concerning the effects of school ground lessons on scientific curiosity. Internal inspiration that drives students to know more about science as what Harty and Beall (1984) defined as scientific curiosity is affected by the factors of novelty, lack of clarity, complexity of stimuli and surprise or bafflement. Unfortunately these factors have little been researched among primary school students in school ground lessons. This study was thus undertaken to find out if outdoor school ground lessons would give any effects on science process skills (SPS) and scientific curiosity (SC) of Year Five students (mean age 11 years old). In order to examine the treatment effects, the participants in the study were divided into two groups. The students who received the intervention of outdoor school ground lessons were defined as "eco-hunt" group. On another hand, the students who received ordinary teaching methods, such as, whiteboard, textbook, slideshows teaching group were defined as control group. The specific research hypotheses of this study were:

1) There is no significant difference between students learning in "eco-hunt" group and control group in i) pre-test mean scores in SPS, and ii) post-test mean scores in SPS .

2) There is no significant difference between pre-test mean scores and post-test mean scores in SPS among students in i) "eco-hunt" group, and ii) control group.

3) There is no significant difference between students learning in "eco-hunt" group and control group in i) pre-test mean scores in SC, and ii) post-test mean scores in SC.

4) There is no significant difference between pre-test mean scores and post-test mean scores in SC among students in i) "eco-hunt" group, and ii) control group.

\section{Method}

This study employed a quasi-experimental pre-test-post-test control group design. According to Christensen (2004), "quasi-experimental designs are the best type of design available for use in some field studies in which one wants to make causal inferences" (p. 320). However, a quasi-experimental design is an experimental design that does not meet all the requirements necessary for controlling the influence of extraneous variables (Christensen, 2004). In order to minimize the influence of extraneous variables, the participants in the study were divided into two groups, one subjected to the experimental treatment and defined as "eco-hunt" group and the other has no experimental treatment defined as control group. The control group is important for drawing stronger causal inferences that need to be compared with the results between experimental group and control group (Christensen, 2004).

A convenient sampling was chosen in this study. The study included those subjects that are immediately to hand which requires lesser time and cheaper cost. A convenient sampling is more practical because the subjects are easily assessable (Allison et al., 1996). Therefore, two of the four intact classes of Year Five students in one primary school in Kota Kinabalu were chosen to be the experimental group $(n=63)$ and control groups $(n=56)$ respectively.

The instruments used to measure the science process skills and scientific curiosity of students were Science Process Skills Test and Children's Scientific Curiosity Scale respectively. The study used two equivalent Science 
Process Skills (SPS) tests in which each consisted of 20 items posed in multiple-choice format that tested the science process skills of observing, classifying, making inferences, predicting, communicating and controlling variables. These test items were constructed by referring to the levels which has been stated in school-based Practical Work Assessment or in its Malay acronym, PEKA (Penilaian Kerja Amali). The SPS Test took approximately 20 to 30 minutes for administration. The scores of both tests were compared using Pearson product-moment correlation coefficient. The correlation coefficient for two equivalent forms of SPS test was found to be 0.736 which showed that both equivalent forms of SPS tests were highly and positively correlated with one another, which means that the SPS test was reliable. In order to ensure the content validity of the SPS test was fulfilled, two senior science teachers were assigned to evaluate the test items according to Practical Work Assessment and Standard Curriculum for Primary School.

The Children's Scientific Curiosity Scale (CSCS) used in this study was adapted from Harty and Beall (1984). The CSCS composed of 30 Likert-type items which examined four generic curiosity factors or dimensions in the context of science learning: novelty, lack of clarity, complexity of stimuli and surprise or bafflement. The administration time for CSCS took approximately 20 to 30 minutes. The reliability of CSCS was tested with Cronbach's alpha. The Cronbach's alpha for CSCS was found satisfactory (0.830), which means that the CSCS was reliable. According to Crano and Brewer (1973), a minimum alpha coefficient for Likert-type scales is 0.80 . The procedure used by this study to ensure the construct validity of CSCS was to assign an expert in science education to judge the items to the construct of the CSCS was meant to measure.

The intervention took about four to six weeks. At the beginning of the intervention, both the control groups and the "eco-hunt" groups participated in the pre-test of science process skills (SPS) and scientific curiosity (SC). The pre-test was helpful in assessing students' prior knowledge of SPS and SC respectively and also in testing initial equivalence among groups. Then, the "eco-hunt" groups took part in the outdoor school ground lessons. However, the control group received the ordinary teaching and learning process, such as teaching by wall-charts, textbooks, power point slides and other methods. Four lessons that apply the outdoor school ground lessons as shown in Table 1 were designed to teach the specific topics.

Students in the "eco-hunt" group were facilitated to foster their science process skills of observing, predicting and making inference throughout the school ground lessons I-IV. Students developed their skills of observing when they were asked to access the school ground to seek for animals and plants. Teacher also drew students' attention to a variety of questions that would foster their skills of predicting and making inference. Students would soon develop their skills of classifying as they divided animals into groups of "taking care and not taking care of their young" during lesson one; and classified plants according to the methods of dispersion in lesson two. Students needed to present information using food chains and food webs in lesson three and four, this will help them to improve their communicating skills. Students then stated how the numbers of producers and consumers would affect one another, thus helped them to develop the skills of controlling variables.

In addition, the process of discovering animals and plants that might appear in the school ground would help to enhance student's "novelty" in scientific curiosity. What's more, students would interact with teacher and ask question throughout the lessons; this process would help to improve "lack of clarity" in scientific curiosity. Besides, students needed to use a variety of senses while they were seeking for and observing the animals and plants; this would help to provoke "complexity of stimuli". During lesson three and four, students will identify the relationships between animals and plants in the process of constructing food chains and food webs. Students will learn how the animals and plants affect one another, this will help to arouse "surprise/bafflement" in scientific curiosity.

For the control groups, students received a conventional teaching and learning process. Teacher taught the lessons using textbooks, wall charts and slides that consisted of pictures of different plants and animals. At the end of the intervention, the post-test of science process skills and scientific curiosity were administered to both the control groups and the "eco-hunt" groups in order to measure the treatment effects. 
Table 1. Structures of outdoor school ground lessons

\begin{tabular}{|c|c|c|c|c|}
\hline Lessons & Topics & $\begin{array}{l}\text { Learning } \\
\text { Area }\end{array}$ & Activities & SPS/SC \\
\hline 1 & $\begin{array}{l}\text { Animal } \\
\text { Survival }\end{array}$ & $\begin{array}{l}\text { Survival } \\
\text { of animal } \\
\text { species. }\end{array}$ & $\begin{array}{l}\text { Students accessed the school ground to look for any } \\
\text { kind of animals that would appear, for example, } \\
\text { lizard, butterfly, grasshopper, bird, earthworm and } \\
\text { others. Students wrote down the names or drew the } \\
\text { animals. Teacher grouped students in the school } \\
\text { compound and discussed with students how these } \\
\text { animals would ensure the survival of their species. For } \\
\text { example, birds fed their young to protect them. }\end{array}$ & $\begin{array}{l}\underline{\text { SPS }} \\
\text { Observing, making } \\
\text { inference, } \\
\text { predicting, } \\
\text { classifying } \\
\underline{\text { SC }} \\
\begin{array}{l}\text { Novelty, lack of } \\
\text { clarity, complexity } \\
\text { of stimuli }\end{array}\end{array}$ \\
\hline 2 & $\begin{array}{l}\text { Plant } \\
\text { Survival }\end{array}$ & $\begin{array}{l}\text { Survival } \\
\text { of plant } \\
\text { species. }\end{array}$ & $\begin{array}{l}\text { Students accessed the school ground to find out the } \\
\text { plants requested by teacher. Students drew or wrote } \\
\text { down the characteristics of the plants. Teacher } \\
\text { grouped students in the school compound and } \\
\text { collected their works. Teacher related students' results } \\
\text { with the learning content, which were the methods of } \\
\text { plants to ensure their survival of species. For example, } \\
\text { papaya plants dispersed their seeds by animal; the } \\
\text { fruits were colorful and smelled good in order to } \\
\text { attract animals. }\end{array}$ & $\begin{array}{l}\underline{\text { SPS }} \\
\text { Observing, making } \\
\text { inference, } \\
\text { predicting, } \\
\text { classifying } \\
\underline{\text { SC }} \\
\begin{array}{l}\text { Novelty, lack of } \\
\text { clarity, complexity } \\
\text { of stimuli }\end{array}\end{array}$ \\
\hline 3 & $\begin{array}{l}\text { Food } \\
\text { Chain }\end{array}$ & $\begin{array}{l}\text { Food } \\
\text { chain. }\end{array}$ & $\begin{array}{l}\text { Students accessed the school ground to seek for the } \\
\text { plants which acted as a producer in a food chain. } \\
\text { Teacher gathered students in the school compound and } \\
\text { asked students to state the animals that would eat the } \\
\text { plants. Teacher guided students to form a food chain } \\
\text { which began with the plant. As an example, } \\
\text { grasshoppers eat grass, birds eat grasshopper. } \\
\text { grass } \rightarrow \text { grasshopper } \rightarrow \text { bird } \\
\text { Students gathered all information provided by the } \\
\text { other groups and formed the related food chains that } \\
\text { might appear in the school ground with the concept of } \\
\text { "who eats who". }\end{array}$ & $\begin{array}{l}\text { SPS } \\
\text { Observing, } \\
\text { predicting, making } \\
\text { inference, } \\
\text { communicating, } \\
\text { controlling } \\
\text { variables }\end{array}$ \\
\hline 4 & $\begin{array}{l}\text { Food } \\
\text { Web }\end{array}$ & Food web. & $\begin{array}{l}\text { Students accessed the school ground to find out all the } \\
\text { animals that might appear. Students wrote down the } \\
\text { names or drew the animals. Teacher gathered students } \\
\text { in the school compound and discussed the results with } \\
\text { students. Teacher guided students to construct a food } \\
\text { web using the found animals. As an example, students } \\
\text { found grasshopper, birds and praying mantis. Teacher } \\
\text { guided students to construct a food web as follow: }\end{array}$ & $\begin{array}{l}\text { SPS } \\
\text { Observing, } \\
\text { predicting, making } \\
\text { inference, } \\
\text { communicating, } \\
\text { controlling } \\
\text { variables }\end{array}$ \\
\hline & & & $\begin{array}{l}\text { grass } \longrightarrow \text { grasshopper } \\
\text { Students might construct different food webs when } \\
\text { they tried to link their own food chain with food chain } \\
\text { produced by other groups. }\end{array}$ & $\begin{array}{l}\underline{\mathrm{SC}} \\
\text { Lack of clarity, } \\
\text { complexity of } \\
\text { stimuli, } \\
\text { surprise/bafflement }\end{array}$ \\
\hline
\end{tabular}




\section{Results}

\subsection{Science Process Skills}

There is no significant difference between students learning in "eco-hunt" group and control group in i) pre-test mean scores in SPS, and ii) post-test mean scores in SPS.

An independent-samples t-test was conducted to compare the mean scores of pre-test in science process skills between "eco-hunt" group and control group. Based on the pre-test data shown in Table 2, the significant value of $p=.510$ was greater than significance level of 0.05 . Hence, it was concluded that there was no significant difference in pre-test mean scores between "eco-hunt" group and control group $(\mathrm{t}(117)=.660, \mathrm{p}=.510)$ in science process skills. According to Gay and Airasian (2003, p. 467), if there is no significant difference between the two pre-test means, then a t test can be computed on the post-test means. An independent-samples t-test was therefore conducted to compare the mean scores of post-test in science process skills between "eco-hunt" group and control group. From the post-test data shown Table 2, the significant value of $p<.001$ was smaller than significance level of 0.05 , thus there was a significant difference in post-test mean scores between "eco-hunt" group and control group $(\mathrm{t}(117)=4.241, \mathrm{p}<.001)$ in science process skills.

Table 2. Science process skills between groups in Pre- and Post-Test

\begin{tabular}{lllllll}
\hline Variables Test & Eco-hunt & Control & Mean & $\mathrm{t}$ & $\mathrm{df}$ & $\mathrm{p}$ \\
\cline { 2 - 3 } Mean(SD) & Mean(SD) & difference & & & \\
\hline Science & 33.81 & 32.50 & 1.31 & & & \\
Process Skills Pre & $(11.098)$ & $(10.445)$ & & .660 & 117 & .510 \\
Science & 58.10 & 41.25 & & & & \\
Process Skills Post & $(22.548)$ & $(20.544)$ & 16.845 & 4.241 & 117 & $.000^{*}$ \\
\hline
\end{tabular}

* Significant at $\mathrm{p}<.05$ level.

There is no significant difference between pre-test mean scores and post-test mean scores in SPS among students in i) "eco-hunt" group, and ii) control group.

A paired-samples t-test was conducted to determine the difference between pre-test mean scores and post-test mean scores within "eco-hunt" group and control group in science process skills. From the Table 3, the significant value of $\mathrm{p}<.001$ was smaller than significance level of 0.05 , thus, there was a significant difference from the mean scores of pre-test to post-test $(\mathrm{t}(62)=-9.882, \mathrm{p}<.001)$ in science process skills of "eco-hunt" group. Based on the data in Table 3, significant value of $p=.001$ was smaller than significance level of 0.05 , hence, there was a significant difference from the mean scores of pre-test to post-test $(\mathrm{t}(55)=-3.391, \mathrm{p}=.001)$ in science process skills of control group.

Table 3. Science process skills between pre-test and post-test of "eco-hunt" group and control group

\begin{tabular}{llllllll}
\hline Variables & Group & Pretest & Posttest & Mean & $\mathrm{t}$ & $\mathrm{df}$ & $\mathrm{p}$ \\
\cline { 3 - 4 } & & Mean(SD) & Mean(SD) & difference & & & \\
\hline $\begin{array}{l}\text { Science } \\
\text { Process Skills }\end{array}$ & Eco-hunt & 33.81 & 58.10 & 24.286 & -9.882 & 62 & $.000^{*}$ \\
$\begin{array}{l}\text { Science } \\
\text { Process Skills }\end{array}$ & Control & 32.50 & 41.25 & & & & \\
\hline
\end{tabular}

* Significant at $\mathrm{p}<.05$ level.

From the findings above, both groups performed significantly better on the post test compared to the pre test in science process skills. However, the average increase in mean scores of 24.286 in "eco-hunt" group was higher 
than the average increase in mean scores of 8.750 in control group. From the results stated above, the outdoor school ground lessons showed better effects on students' science process skills.

Besides, the present study also analyzed the findings according the dimensions of Science Process Skills Test in order to evaluate the improvements of each dimensions in "eco-hunt" group. The dimensions tested in Science Process Skills Test included: observing, classifying, making inferences, predicting, communicating and controlling variables. Mean scores and percentages of each dimension were computed to determine the effects of outdoor school ground lessons on each dimension of science process skills. Table 4 shows the comparison of means and percentages for each dimension for "eco-hunt" group in Science Process Skills Test using paired-sample t-test, with significance level, alpha $=.05$. A paired-samples t-test was conducted to determine if a significant difference existed between pre-test mean scores or percentages and post-test mean scores or percentages within "eco-hunt" group in each dimension of science process skills. The results shows a significant positive increase from pre-test to post-test in all dimensions of science process skills, such as observing (p $<.001)$, classifying $(\mathrm{p}<.001)$, making inference $(\mathrm{p}=.002)$, predicting $(\mathrm{p}=.024)$, communicating $(\mathrm{p}<.001)$ and controlling variables $(\mathrm{p}<.001)$.

Table 4. Mean/percentage difference of dimensions in science process skills between pre-test and post-test of "eco-hunt" group

\begin{tabular}{|c|c|c|c|c|c|c|c|}
\hline Dimension & $\mathrm{n}$ & $\begin{array}{l}\text { Pretest } \\
\text { Mean/\% } \\
(\mathrm{SD})\end{array}$ & $\begin{array}{l}\text { Posttest } \\
\text { Mean/\% } \\
\text { (SD) }\end{array}$ & $\begin{array}{l}\text { Mean/\% } \\
\text { Difference }\end{array}$ & $\mathrm{t}$ & $\mathrm{df}$ & $\mathrm{p}$ \\
\hline Observing & 63 & $\begin{array}{l}6.587 / 32.9 \\
(4.564)\end{array}$ & $\begin{array}{l}11.746 / 58.7 \\
(6.907)\end{array}$ & $\begin{array}{l}5.159 / \\
25.8\end{array}$ & -5.792 & 62 & $.000^{*}$ \\
\hline Classifying & 63 & $\begin{array}{l}5.635 / 28.2 \\
(3.647)\end{array}$ & $\begin{array}{l}13.492 / 67.5 \\
(5.932)\end{array}$ & $\begin{array}{l}7.857 / \\
39.3\end{array}$ & -9.221 & 62 & $.000 *$ \\
\hline $\begin{array}{l}\text { Making } \\
\text { Inference }\end{array}$ & 63 & $\begin{array}{l}4.921 / 24.6 \\
(4.065)\end{array}$ & $\begin{array}{l}7.698 / 38.5 \\
(5.066)\end{array}$ & $\begin{array}{l}2.778 / \\
13.9\end{array}$ & -3.230 & 62 & $.002 *$ \\
\hline Predicting & 63 & $\begin{array}{l}4.206 / 21 \\
(4.232)\end{array}$ & $\begin{array}{l}6.032 / 30.2 \\
(4.504)\end{array}$ & $\begin{array}{l}1.825 / \\
9.2\end{array}$ & -2.321 & 62 & $.024 *$ \\
\hline Communicating & 63 & $\begin{array}{l}6.191 / 31 \\
(3.885)\end{array}$ & $\begin{array}{l}9.841 / 49.2 \\
(4.576)\end{array}$ & $\begin{array}{l}3.651 / \\
18.2\end{array}$ & -5.686 & 62 & $.000^{*}$ \\
\hline $\begin{array}{l}\text { Controlling } \\
\text { variables }\end{array}$ & 63 & $\begin{array}{l}6.269 / 31.4 \\
(5.310)\end{array}$ & $\begin{array}{l}9.286 / 46.4 \\
(5.740)\end{array}$ & $\begin{array}{l}3.016 / \\
15\end{array}$ & -3.677 & 62 & $.000^{*}$ \\
\hline
\end{tabular}

* Significant at $\mathrm{p}<.05$ level.

Based on the percentage shown in Table 4, the students have the greatest improvement in the dimension of classifying with a $39.3 \%$ increase from pre to post-test. Followed by the dimension of observing which showed a $25.8 \%$ increase from pre to post-test. Nevertheless, the dimension of predicting showed the least increment from pre to post-test, that was $9.2 \%$.

\subsection{Scientific Curiosity}

There is no significant difference between students learning in "eco-hunt" group and control group in i) pre-test mean scores in SC, and ii) post-test mean scores in SC.

An independent-samples t-test was conducted to compare the mean scores of pre-test in scientific curiosity between "eco-hunt" group and control group. From what is shown in Table 5, the significant value of $p=.056$ was greater than significance level of 0.05 , thus there was no significant difference in pre-test mean scores between "eco-hunt" group and control group $(\mathrm{t}(117)=1.930, \mathrm{p}=.056)$ in scientific curiosity. An independent-samples t-test was therefore conducted to compare the mean scores of post-test in scientific curiosity between "eco-hunt" group and control group. From the Table 5 stated, the significant value of $p<.001$ 
was smaller than significance level of 0.05 , thus there was a significant difference in post-test mean scores between "eco-hunt" group and control group $(t(117)=5.394, p<.001)$ in scientific curiosity.

Table 5. Scientific curiosity mean difference between "eco-hunt" group and control group in pre- and post-test

\begin{tabular}{lcllllll}
\hline Variables & Test & Eco-hunt & Control & Mean & $\mathrm{t}$ & $\mathrm{df}$ & $\mathrm{p}$ \\
\cline { 3 - 7 } & & Mean(SD) & Mean(SD) & difference & & & \\
\hline $\begin{array}{l}\text { Scientific } \\
\text { Curiosity }\end{array}$ & Pre & 109.54 & 105.18 & 4.361 & 1.930 & 117 & .056 \\
Scientific & Post & $(13.338)$ & $(11.026)$ & & & & \\
Curiosity & & $(15.70$ & 99.55 & 15.145 & 5.394 & 117 & $.000^{*}$ \\
\hline
\end{tabular}

* Significant at $\mathrm{p}<.05$ level.

There is no significant difference between pre-test mean scores and post-test mean scores among students in scientific curiosity in i) "eco-hunt" group, and ii) control group.

A paired-samples t-test was conducted to determine the difference between pre-test mean scores and post-test mean scores within "eco-hunt" group and control group in scientific curiosity. From the Table 6, the significant value of $\mathrm{p}=.010$ was smaller than significance level of 0.05 , thus, there was a significant difference from the mean scores of pre-test to post-test $(\mathrm{t}(62)=-2.641, \mathrm{p}=.010)$ in scientific curiosity of "eco-hunt" group. Based on the data in Table 6 , significant value of $p=.007$ was smaller than significance level of 0.05 , hence, there was a significant difference from the mean scores of pre-test to post-test $(\mathrm{t}(55)=-2.822, \mathrm{p}=.007)$ in scientific curiosity of control group.

Table 6. Scientific curiosity mean difference between pre-test and post-test in "eco-hunt" group and control group

\begin{tabular}{llllllll}
\hline Variables & Group & Pretest & Posttest & Mean & $\mathrm{t}$ & $\mathrm{df}$ & $\mathrm{p}$ \\
\cline { 3 - 7 } & & Mean(SD) & Mean(SD) & difference & & & \\
\hline Scientific & Eco-hunt & 109.54 & 114.70 & 5.159 & -2.641 & 62 & $.010^{*}$ \\
Curiosity & & $(13.338)$ & $(15.508)$ & & & & \\
Scientific & Control & 105.18 & 99.55 & -5.625 & 2.822 & 55 & $.007^{*}$ \\
Curiosity & & $(11.026)$ & $(15.033)$ & & & & \\
\hline
\end{tabular}

* Significant at $\mathrm{p}<.05$ level.

From the findings above, both groups showed statistically significant difference in mean scores between pre-test and post-test in scientific curiosity. Anyhow, an increase mean score of 5.159 in "eco-hunt" group was found, on the contrary, a decrease mean score of 5.625 was observed in control group. From the results stated above, the outdoor school ground lessons showed better effects on students' scientific curiosity.

In addition, the present study analyzed the findings according the dimensions of Children's Scientific Curiosity Scale to evaluate the improvements of each dimensions in "eco-hunt" group. The dimensions of Children's Scientific Curiosity Scale included novelty, lack of clarity, complexity of stimuli and surprise or bafflement. Mean scores and percentages of each dimension were computed to determine the effects of outdoor school ground lessons on each dimension in scientific curiosity. Table 7 shows the comparison of mean and percentage for each dimension for "eco-hunt" group in Scientific Curiosity Scale using paired-sample t-test, with significance level, alpha $=.05$. A paired-samples t-test was conducted to determine the difference between pre-test mean scores or percentages and post-test mean scores or percentages within "eco-hunt" group in each dimension of scientific curiosity. The results shows that there was a significant positive increase from pre-test to post-test in some of the dimensions of scientific curiosity, such as novelty $(p=.001)$ and complexity of stimuli ( $p$ $<.001)$. However, there was no significant difference between pre-test and post-test mean score in the dimensions of lack of clarity and surprise or bafflement. 
Table 7. Mean/percentage difference of dimensions in scientific curiosity between pre-test and post-test of "eco-hunt" group

\begin{tabular}{|c|c|c|c|c|c|c|c|}
\hline \multirow[t]{2}{*}{ Dimension } & \multirow[t]{2}{*}{$\mathrm{n}$} & \multirow{2}{*}{$\begin{array}{l}\text { Pretest } \\
\text { Mean } / \% \\
(\mathrm{SD})\end{array}$} & \multirow{2}{*}{$\begin{array}{l}\text { Posttest } \\
\text { Mean/\% } \\
(\mathrm{SD})\end{array}$} & \multirow{2}{*}{$\begin{array}{l}\text { Mean/\% } \\
\text { Difference }\end{array}$} & \multirow[t]{2}{*}{$\mathrm{t}$} & \multirow[t]{2}{*}{$\mathrm{df}$} & \multirow[t]{2}{*}{$\mathrm{p}$} \\
\hline & & & & & & & \\
\hline Novelty & 63 & $\begin{array}{l}35.302 / 23.9 \\
(6.505)\end{array}$ & $\begin{array}{l}38.698 / 25.8 \\
(6.909)\end{array}$ & $\begin{array}{l}3.396 / \\
2.3\end{array}$ & -3.37 & 62 & $.001^{*}$ \\
\hline Lack of Clarity & 63 & $\begin{array}{l}35.444 / 23.6 \\
(7.596)\end{array}$ & $\begin{array}{l}35.191 / 23.5 \\
(6.758)\end{array}$ & $\begin{array}{l}-.254 / \\
-0.1\end{array}$ & .225 & 62 & .823 \\
\hline $\begin{array}{l}\text { Complexity of } \\
\text { Stimuli }\end{array}$ & 63 & $\begin{array}{l}26.016 / 17.3 \\
(5.078)\end{array}$ & $\begin{array}{l}35.191 / 23.5 \\
(6.758)\end{array}$ & $\begin{array}{l}9.175 / \\
6.2\end{array}$ & -8.786 & 62 & $.000^{*}$ \\
\hline $\begin{array}{l}\text { Surprise/ } \\
\text { Bafflement }\end{array}$ & 63 & $\begin{array}{l}12.778 / 8.5 \\
(2.303)\end{array}$ & $\begin{array}{l}12.492 / 8.3 \\
(2.242)\end{array}$ & $\begin{array}{l}-.286 / \\
-0.2\end{array}$ & .826 & 62 & .412 \\
\hline
\end{tabular}

* Significant at $\mathrm{p}<.05$ level.

Based on the percentage shown in Table 7, the students showed the greatest improvement in the dimension of complexity of stimuli with a $6.2 \%$ increase from pre to post-test. This was follow by the dimension of novelty which showed a $2.3 \%$ increase from pre to post-test. Anyway, the dimension of lack of clarity and surprise or bafflement showed a decrement of $0.1 \%$ and $0.2 \%$ from pre to post-test respectively.

\section{Discussion}

One of the major questions addressed in this study was whether the use of outdoor school ground lessons would improve students' science process skills. It was found that students in both groups had significantly higher science process skills mean scores in post-test compared to pre-test, but the outdoor school ground lesson was found to have significantly greater improvement scores than the control group. That is, the opportunity to learn with outdoor school ground lesson enhanced students' science process skills. The obtained results were similar with the previous findings (Archie, 2003; National Foundation for Educational Research, 2004; Keil et al., 2009; Buntod, Suksringam, \& Singseevo, 2010). There are several possible explanations for the beneficial effects of outdoor school ground lessons. Learning through outdoor school ground lessons may help students to build more complex cognitive structures with concrete activities in regards to ordinary activities inside the classroom. Through the interactions among environment, students may have come to apply science process skills in order to solve daily problems better. In addition, learning through outdoor school ground lessons may have spurred students to make more explicit links to prior knowledge compared to the individual learning inside the classroom. This could account for their ability to relate science process skills to solve daily problems.

Besides, this study analyzed the findings according to the dimensions of science process skills. It was found that students showed the most increment in the basic science process skills of classifying and observing. The abilities to classify and to observe were improved because extending the learning process into instructional settings beyond the classroom may provide the opportunity to see, touch, taste, smell and hear which require the use of all senses. Students may learn from experiences gained in the outdoor school ground lessons and real understanding occurs. Like what have been addressed in the theory of experiential learning by Kolb (1984), students construct knowledge, skills and values through direct experiences. Moreover, in outdoor settings theoretical concepts can be matched with real-life examples. Students may connect what they have learnt in the classroom with what have been experienced from the outdoor. Therefore, it is likely that the use of outdoor school ground lessons served to improve students' science process skills to a greater extent than the individual learning with ordinary teaching method, which is also supported by American Institute for Research (2005). However, the results indicated that students showed least increment in the basic science process skills of predicting. The process of predicting may require students to apply the prior knowledge to imagine abstractly what is going to happen in the future. This process might need students' ability to think abstractly. Elementary students might encounter difficulty when predicting abstractly. As Piaget (1971) claimed that, during the third cognitive stage (age 7-11) in children development, when physical experience accumulates, a child starts to conceptualize that explains his or her own physical experiences. However, sufficient physical experiences are 
required in order to help a child to think abstractly. This could explain why students showed the least improvement in the basic science process skills of predicting. Students might not be able to accumulate enough physical experiences through outdoor school ground lessons.

Another major questions addressed in this study was whether the use of outdoor school ground lessons would improve students" scientific curiosity. Students in "eco-hunt" group showed a significantly increment in post-test of scientific curiosity. Students in control group showed significantly lower in post-test of scientific curiosity contradictory. That is, learning science with outdoor school ground lessons enhanced students' scientific curiosity. This finding is consistent with the findings of previous study by Erickson (2008) who reported that natural outdoor spaces foster children ability to explore and desire to know. With the same point of view, Little and Wyver (2008) indicated that learning through environment can satisfy children natural curiosity and desire for novelty.

Further with this point of view, this present study attempted to discover more about the effects of outdoor school ground lessons on scientific curiosity. Therefore, the present study analyzed the findings according to four dimensions tested in the Children's Scientific Curiosity Scale: novelty, lack of clarity, complexity of stimuli and bafflement or surprise. The findings showed that students improved the most in the complexity of stimuli then followed by novelty. However, the findings found that there was no improvement in the dimension of lack of clarity and bafflement or surprise after intervention. The improvement in both of the dimension of complexity of stimuli and novelty meet the results of the study by Cantor and Cantor (1964), who claimed that curiosity can be considered as a function of stimulus novelty. According to Cantor and Cantor (1964), curiosity is due to children's familiarity with variety types of stimuli, with more unusual or conflicting stimuli being more "novel". Correspondingly, according Smock and Holt (1962), complexity of stimuli was primarily driven by novelty; plus, they suggested that novelty is more likely a motivator of curiosity. Therefore, it could be explained why the dimension of complexity of stimuli and novelty enhanced at the same time. Anyway, there was no improvement in the dimension of lack of clarity and bafflement or surprise after intervention. Both of the dimensions of lack of clarity and surprise/bafflement are measuring for uncertainty concurrently. Uncertainty occurs when disequilibrium occurs, which is supported by Piaget (1956). Children showed preference to explore the surprise and unexpected condition most when they meet uncertainty situation. On the other hand, according to Charlesworth's theory of curiosity, students would like to explore more to unexpected condition than expected condition when they are seeking for answer (Jirout \& Klahr, 2012). But, in the present study, students were familiar to the currently existing school ground. Therefore, students tend to passively explore to the expected condition. This can be explained why the dimension of lack of clarity and bafflement/surprise showed no improvement after students were being exposed to outdoor school ground lessons.

Generalizing the present study's findings to other elementary school students should be done in caution. The students who served as subjects in this study were selected through convenient sampling that is a non-probability sampling. There is no precise way of generalizing from a convenience sampling to a population. It is recommended to use randomization in the future studies in order to draw a stronger causal inference. In regard to the instruments of this study, Science Process Skills Test and Children's Scientific Curiosity Scale were used to obtain students' responses which relied on students' self-reports. There is a second major type of data collection which does not rely on self-reports; it is the observation method. Observation allows a clear description of behavior as it occurs naturally.

Based on the results of this study, it provides an additional instructional teaching method to educators which might help in teaching. This study will provide a framework for science teachers to teach students through interesting and meaningful outdoor activities. Besides, teacher training institutes may use this study as a guideline for a further research in outdoor education. Outdoor educations not only enhance students' science process skills and curiosity toward science, it might have other beneficial aspects that this study has not yet explored. Moreover, the results of this study may help in science curriculum development. With the results that outdoor school ground lesson has improved students' science process skills and scientific curiosity; curriculum developer might consider putting outdoor school lessons into science curriculum.

\section{References}

Akinbobola, A. O., \& Afolabi, F. (2010). Analysis of science process skills in West African senior secondary school of certificate Physics practical examinations in Nigeria. American-Eurasian Journal of Scientific Research, 5(4), 234-240.

Allison, B., O’Sullivan, T., Owen, A., Rice, J., Rothwell, A., \& Saunders, C. (1996). Research Skills for Students. London: Kogan Page. 
Alpay, E. (2003). The contribution of Vygotsky's theory to our understanding of the relation between the social world and cognitive development. In W. G. Huit (Ed.), Educational Psychology Interactive: Readings in Educational Psychology. Valdosta State University, GA.

American Institutes for Research. (2005). Effects on Outdoor Education Program for Children in California. The California Department of Education.

Archie, M. (2003). Advancing Education through Environmental Literacy. Alexandria, VA: Association for Supervision and Curriculum Development.

Artun, H., \& Coștu, B. (2013). Effect of the 5E model on prospective teachers' conceptual understanding of diffusion and osmosis: A mixed method approach. Journal of Science Education and Technology, 22(1), 1-10. http://dx.doi.org/10.1007/s10956-012-9371-2

Berlyne, D. E. (1954). An experimental study of human curiosity. British Journal of Psychol, 45, 256-265.

Borowske, K. (2005). Curiosity and Motivation-to-Learn. ACRL Twelfth National Conference, Minneapolis, Minnesota. Retrieved from http://www.ala.org/ala/acrl/acrlevents/borowske05.pdf

BSCS. (2006). The BSCS 5E Instructional Model: Origins and Effectiveness. Dubuque, IA: Kendall/Hunt Publishing Company.

Buntod, P., C., Suksringan, P., \& Singsreevo, A. (2010). Effects of learning environmental education on science process skills and critical thinking of Mathayomsuksa 3 students with different learning achievement. Journal of Social Sciences, 6(1), 60-63. http://dx.doi.org/10.3844/jssp.2010.60.63

Burek, K. (2012). The Impact of Socioscientific Issues Based Curriculum Involving Environmental Outdoor Education for Forth Grade Students. Graduate School Theses and Dissertations. University of South Florida.

Cardak, O., Dikmenli, M., \& Saritas, O. (2008). Effect of 5E instructional model in student success in primary school 6th year circulatory system topic. Asia-Pacific Forum on Science Learning and Teaching, 9(2), 1-11.

Carrier, S. J. (2009). The effects of outdoor science lessons with the elementary school students on preservice teachers' self-efficacy. Journal of Elementary Science Education, 21(2), 35-48. http://dx.doi.org/10.1007/BF03173683

Christensen, L. B. (2004). Experimental Methodology. United State of America: Pearson.

Crano, W. D., \& Brewer, M. B. (1973). Principles of research in social psychology. New York: McGraw-Hill.

Curriculum Development Centre. (2006). Integrated Curriculum For Secondary Schools-Curriculum Specifications Science Year 5. Ministry of Education Malaysia.

Dietz, K. A. (2002). Influence of teaching in an outdoor classroom on kindergarten children's comprehension and recall of a science lesson. (Unpublished Master Dissertation). University of Louisianna Lafayette, United State.

Eaton, D. (1998). Cognitive and Affective Learning in Outdoor Education. (Doctoral Dissertation). UMI 800-521-0600.

Edelman, S. (2007). Curiosity and Exploration. Retrieved from http://www.csun.edu/ vcpsy00h/students/explore.htm

El-Aziz, H. A. (2011). The impact of a web-based virtual lab on the development of students' conceptual understanding and science process skills (Unpublished Doctoral Dissertation). Mansoura University, Egypt.

Elvan, I. A., Ezgi, G., \& Mustafa, A. (2010). Effects of problem solving method on science process skills and academic achievement. Journal of Turkish Science Education, 7(4), 13-25.

Erickson, M. F. (2008). The children and nature network-Ensuring that all children can spend quality time outdoors. Retrieved from http://www.naeyc.org/files/yc/file/200801/BTJNatureErickson.pdf

Fiskum, T. A., \& Jacobsen, K. (2012). Individual differences and possible effects from outdoor education: Long time and short time benefits. World Journal of Education, 2(4), 20-33. http://dx.doi.org/10.5430/wje.v2n4p20

Gay, L. R., \& Airasian, P. W. (2003). Educational Research: Competencies or Analysis and Applications. Merrill: Prentice Hall. 
Green, S. B., \& Salkind, N. J. (2012). Using SPSS for Windows and Macintosh: Analyzing and Understanding data (6th ed.). United States of America: Pearson.

Gustafsson, P. E., Szczepanski, A., Nelson, N., \& Gustafsson, P. A. (2011). Effects of an outdoor education Intervention on the mental health of schoolchildren. Journal of Adventure Education and Outdoor Learning, $1,1-17$.

Harty, H., \& Beall, D. (1984). Toward the development of a children's science curiosity measure. Journal of Research in Science Teaching, 21(4), 425-436. http://dx.doi.org/10.1002/tea.3660210410

Harvey, M. R. (1989-1990). The relationship between children's experiences with vegetation on school grounds and their environmental attitudes. The Journal of Environmental Education, 21(2), 9-1. http://dx.doi.org/10.1080/00958964.1990.9941926

Jirout, J., \& Klahr, D. (2012). Children's scientific curiosity: In search of an operational definition of an elusive concept. Developmental Review, 32(20), 125-160. http://dx.doi.org/10.1016/j.dr.2012.04.002

Jones, M. (2009). Back-translation: The latest form of plagiarism (pp. 1-7). The 4th Asia Pacific Conference on Educational Integrity. Wollongong, Australia: University of Wollongong.

Jones, M. G., \& Brader-Araje, L. (2002). The impact of constructivism on education: Language, discourse, and meaning. American Communication Journal, 5(3). Retrieved from http://ac-journal.org/journal/vol5/iss3/special/jones.pdf

Karamustafaoğlu, S. (2011). Improving the science process skills ability of science student teachers using I diagram. Eurasian Journal of Physics and Chemistry Education, 3(1), 26-38.

Keil, C., Haney, J., \& Zoffel, J. (2009). Improvement in student achievement and science process skills using environmental health science problem-based learning curricula. Electronic Journal of Science Education, 13(1). Retrieved from http://ejse.southwestern.edu.

Keller, J. M. (1987). Development and use of the ARCS model of motivational design. Journal of Instructional Development, 10(3), 2-10. http://dx.doi.org/10.1007/BF02905780

Kolb, D. A. (1984). Experiential learning: Experience as the source of learning and development. Englewood Cliffs, NJ: Prentice Hall.

Lay, Y. F. (2009). The influence of science process skills, logical thinking abilities, attitudes towards science and locus of control on science achievement among Form 4 students in the interior division of Sabah, Malaysia. Journal of Science and Mathematics Education in S.E. Asia, 31(1), 79-99.

Lay, Y. F., \& Khoo, C. H. (2009). Pengenalan kepada Analisis Data Komputer dengan SPSS 16.0. Kota Kinabalu: Penerbit Universiti Malaysia Sabah.

Lay, Y. F., \& Khoo, C. H. (2012). Pengenalan kepada Pendekatan Kuantitatif dalam Penyelidikan Pendidikan. Kota Kinabalu: Penerbit Universiti Malaysia Sabah.

Leupp, A. (2007). Gendered wilderness: The effect of outdoor education on girls' and boys' self-concept. An Undergraduate Research Journal, 10(1), 73-88.

Lewis-Beck, M. S. (1993). Experimental Design \& Methods. United Kingdom: Sage Publication Ltd.

Litman, J. A. (2005). Curiosity and the pleasure of learning: Wanting and liking new information. Cognition and Emotion, 19(6), 793-814. http://dx.doi.org/10.1080/02699930541000101

Little, H., \& Wyver, S. (2008). Outdoor play: Does avoiding the risks reduce benefits? Australian Journal of Early Childhood, 33(2), 33-40.

Loewenstein, G. (1994). The psychology of curiosity: A review and reinterpretation. Psychological Bulletin, 116(1), 75-98. http://dx.doi.org/10.1037/0033-2909.116.1.75

Martin, M. O., Mullis, I. V. S., Foy, P., \& Stanco, G. M. (2012). TIMSS 2011 International Results. Chestnut Hill: TIMSS \& PIRLS International Study Center, Boston College.

Martin, S. C. (2003). The influence of outdoor schoolyard experiences on students' environmental knowledge, attitudes, behaviors, and comfort level. Journal of Elementary Science Education, 15(2), 51-63. http://dx.doi.org/10.1007/BF03173843

McMillan, J. H. (2012). Educational Research: Fundamentals for the consumer. United States of America: Pearson. 
Miles, E. (2010). In-Service Elementary Teachers' Familiarity, Interest, Conceptual Knowledge, and Performance on Science Process Skills. (Unpublished Master Theses). Southern Illinois University Carbondale, United State.

Mutlu, M., \& Temiz, B. K. (2013). Science process skills of students having field dependent and field independent cognitive styles. Academic Journal, 8(11), 766-776.

National Childcare Campaign. (2011). Forest School-Outdoor Fun and Learning. Retrieved from http://www.daycaretrust.org.uk

National Foundation for Educational Research. (2004). A Review Research of Research on Outdoor Learning. London: FSC, Department for Education and Skills, Groundwork, RSPB, WWT, English Outdoor Council, Skills Active and British Ecological Society.

National Wildlife Federation. (2013). Schoolyard Habitats Program. Retrieved from http://www.nwf.org

Ong, E. T., Wong, Y. T., Yassin, S. M., Baharom, S., \& Yahaya, A. (2011). The development and validation of an all-compassing Malaysian-Based science process skills test for secondary schools. Journal of Science and Mathematics Education in Southeast Asia, 34(2), 203-236.

Ong, S. L., Ismail, Z., \& Fong, S. F. (2007). Assessing Competency in Integrated Science Process Skill and relation with Science Achievement. Pusat Pengajian Ilmu Pendidikan: Universiti Sains Malaysia.

Orion, N., \& Hofstein, A. (1991). The measurement of students' attitudes toward scientific field trips. Science Education, 75(5), 513-523. http://dx.doi.org/10.1002/sce.3730750503

Orion, N., \& Hofstein, A. (1994). Factors that influence learning during a scientific field trip in a natural environment. Journal of Research in Science Teaching, 31(10), 1097-1119. http://dx.doi.org/10.1002/tea.3660311005

Orion, N., Hofstein, A., Tamir, P., \& Giddings, G. J. (1997). Development and validation of an instrument for assessing the learning environment of outdoor science activities. Science Education, 81(2), 161-171. http://dx.doi.org/10.1002/(SICI)1098-237X(199704)81:2<161::AID-SCE3>3.0.CO;2-D

Padilla, M. J. (1990). Research Matters-to the Science Teacher. The Science Process Skills. Retrieved from http://www.edu.sfu.ca/narstsite/publications/research/skill.htm

Pallant, J. (2010). A Step by Step guide to Data Analysis Using the SPSS Program: SPSS Survival Manual (4th ed.). New York: McGraw Hill.

Patrick, A. O. (2010). Effects of field studies on learning outcome in Biology. Journal of Human Ecology, 31(3), 171-177.

Standard Curriculum for Primary School. (2013). Standard Documents and Primary Four School-Based Assessment. Ministry of Education Malaysia.

Tal, R. T. (2004). Using field trip to a wetland as a guide for conceptual understanding in environmental education-A case study of a pre-service teacher's research. Chemistry Education: Research and Practice, $5(2), 127-142$.

Tudge, J. R. H., \& Winterhoff, P. A. (1993). Vygotsky, Piaget, and Bandura: Perspectives on the relations between the social world and cognitive development. Human Development, 36, 61-81. http://dx.doi.org/10.1159/000277297

Waltman, M. S. (2002). Developments in constructivist work in communication studies, psychology, and education: introduction to the special section on constructivism. American Communication Journal, 5(3), Retrieved from http://ac-journal.org/journal/vol5/iss3/special/waltman.pdf

Vogt, W. P. (2007). Quantitative Research Methods for Professionals. United States: Pearson.

\section{Copyrights}

Copyright for this article is retained by the author(s), with first publication rights granted to the journal.

This is an open-access article distributed under the terms and conditions of the Creative Commons Attribution license (http://creativecommons.org/licenses/by/3.0/). 